\title{
LIST OF PUBLICATIONS ON RESEARCH \\ AT \\ UNIVERSITY OF WYOMING \\ NATIONAL PARK SERVICE RESEARCH CENTER ${ }^{1}$
}

\section{Altmann, Margaret}

1951 Patterns of herd structure in free-ranging elk. Abstr. Ant. Rec., 3(3): 74 .

1951 Patterns of herd structure in free-ranging elk. Paper presented at the Phil. Meeting of the American Society of Zoologists, Abstr. Anat. Rec., Vol. III, No. 3, Nov. 1951, p. 74 .

1951 A study of behavior in a horse-mule group with animal sociograms. Sociometry, Vol. XIV, No. 4, Dec. 1951.

1952 Social behavior of elk, Cervus canadensis nelsoni, in the Jackson Hole area of Wyoming. Behav., 4(2): 116-143.

1953 Social graces in elk society, Bull. N.Y. Zool. Soc., An. Kingdom, 56(3): 66-72.

1956 Patterns of herd behavior in free-ranging elk of Wyoming, Cervus candensis nelsoni. Zoologica, $41(2): 65-71$.

1956 Two marking devices for large land mammals. J. of Wildl. Mgmt., 20(4): 464. With Richard D. Taber and Anton de Vos.

1956 Patterns of social behavior in big game. Trans. of the $21 \mathrm{st}$ No. Amer. Wildl. Conf., March 5-7, 1956. pp. 538-545.

1958 The flight distance in free-ranging big game. J. of Wild. Mgmt., 22(2): 207-209.

1958 Social integration of the moose calf. An. Behav., 6(3-4): $155-159$.

1959 Group dynamics in Wyoming moose during the rutting season. J. Mammal., 40(3): 420-424.

1960 Moose runs from Sandhill Crane. J. Mammal., 41(4): 525.

1960 The role of juvenile elk and moose in the social dynamics of their species. Zoologica, 45, Pt. 1: 35-39.

\footnotetext{
Updated in 1982
} 
1961 "Teen-age" problems in the wilderness. An. Kingdom, $64(2): 41-44$.

1961 Sex dynamics within kinships of free-ranging wild ungulates. Paper presented at the AAAS Denver meetings, Section $\mathrm{H}$, Symposium on Incest, December 30, 1961.

1963 Naturalistic studies of maternal care in moose and elk. Chapter in Maternal Behavior in Mammals, Ed. by Harriet L. Rheingold. John Wiley \& Sons, pp. 233-253.

1963 Seniors of the wilderness. Animal Kingdom, 66(6): 181-183.

1963 The social role of the aged, wild ungulates. Paper presented at the 34 th meeting of the Colorado-Wyoming Academy of Science. May 3 and 4 , 1963, Fort Collins, Colorado.

1965 Messages in the wild. An. Kingdom, 68(6): 179-182.

1968 Social conduct in and out of the herd. Colo. Quarterly, $16(4): 335-351$.

Armitage, Kenneth B.

1959 Behavior patterns of juvenile yellow-bellied marmots (Marmota flaviventris nosophora Howel1). Anat. Rec., 134(3): 529.

1961 Frequency of melanism in the golden-mantled marmot. J. Mammal., 42(1): 100-101.

1962 Social behavior of a colony of the yellow-bellied marmot (Marmota flaviventris). An. Behav., 10(3-4): 319-331.

Baxter, John W.

1960 Aquatic Hyphomycetes from Wyoming. Mycologia, 52(4): 654-655.

Beetle, Alan A.

1952 A 1951 survey of summer elk range in the Teton Wilderness area. Wyo. Range Mgmt. 51: 1-5.

1957 A study of range condition classes in the Jackson Hole region of Wyoming. Wyo. Range Mgmt. Issue No. 104. (Mimeo)

1959 New names within the section Tridentatae of Artemisia. Rhodora 61: 82-85.

1960 A study of Sagebrush. Bull. 368, Univ. of Wyo. Agri. Exper. Sta., June.

1961 Range Survey in Teton County, Wyoming. Part I. Ecology of 
Range Resources. Bull. 376, Univ. of Wyo. Agri. Exper. Sta., March.

1962 Range Survey in Teton County, Wyoming. Part II. Utilization and Condition Classes, Bull. 400, Univ. of Wyo. Agri. Exper. Sta., Dec.

1964 (With Fronk, W. D. and D. G. Fullerton) Dipterous gall on the Artemisia tridentata complex and insects associated with them. Ann. Entomol. Soc. of Amer. 57: 575-577.

1966 A 1966 survey of summer elk range in southern Yellowstone. Wyo. Range Mgmt. 223: 196-198.

(With Alvin Young) A third spubspecies in the Artemisia tridentata complex. Rhodora 67: 405-406.

1968 Range Survey in Teton County, Wyoming. Part III. Trends in Vegetation. Res. J. 26, Univ. of Wyo. Agri. Exper. Sta., Dec.

Another note on sagebrush taxonomy. Rhodora 70: 782 .

1970 Ecology and carrying capacity of summer elk range. In For. Res. Prog. in 1970. McIntyre-Stennis, pages 34-35, IIlus.

(With M. May) Grasses of Wyoming. Wyo. Agri. Exper. Sta. Res. J. 39: 1-151.

Recommended plant names. Wyo. Agri. Exper. Sta. Res. J. 31: $1-124$.

1971 M. E O. Murie's "Wapati Wilderness". Wyo. Range Mgmt. 286: page 12. (Book Review)

1972 Variation and ecology of aspen. For. Res. Prog. in 1971. page 51 .

Beetle, Dorothy E.

1956 Habitats of terrestrial Mollusca in Jackson Hole, Wyoming J. Colo-Wyo Acad. Sci., 55(8): 43.

1957 The Mollusca of Teton County, Wyoming. The Nautilus, $71(1): 12-22$.

1960 Noteworthy records of Wyoming Mollusca. The Nautilus, $73(4): 155-157$.

A checklist of Wyoming recent Mollusca. Sterkiana, No. 3 . 
Bengham, Ralph

1951 Parasites of fish in the Upper Snake River drainage and in Yellowstone Lake, Wyoming. Zoologica, 36(111).

1953 Studies on monogenetic trematodes: Dactylogyridae from Alaska, Wisconsin and Wyoming. Am. Mid. Nat., 50(1): 206-217. Published by John D. Mizelle and Francis 0. Webb using Bengham's material.

Hypocaryopllaeus gilae n. sp. (Caryophyllaeidae) from the Utah chub, Gilla atraria, in Wyoming. Proc. Helm. Soc. Wash., 20(2): 113-117. Published by Jacob H. Fischehal using Bengham's material.

Bergstrom, Robert C.

1975 The prevalence of Dictyocaulus viviparus infection in Rocky Mountain elk in Teton County, Wyoming. J. Wildl. Dis., 11: $40-44$.

Bergstrom, Robert C. \& R. Robbins

1979 Lungworms, Dictyocaulus viviparus, in various age classes of elk (Cervus canadensis) in the Tetons, In "North American Elk Ecology"! Ecol. Beha. and Management. Symposium. Univ. of Wyo. April 3-5, 1978. pp. 221-223.

Bick, George H. and Lothar E. Hornuff

1972 Odonata collected in Wyoming, South Dakota, and Nebraska.

Proc. Ent. Soc. of Wash., 74(1): 1-8.

Bliss, L. C.

1956 A comparison of plant development in microenvironments of arctic and alpine tundras. Ecol. Mon., 26: 303-337.

Calder, William A., Jr.

1968 . Temperature relations and underwater endurance of the smallest homeothermic diver. Amer. Zool., 8(4): 145.

1969 Temperature relations and underwater endurance of the smallest homeothermic diver, the water shrew. Comp. Biochem. Physiol., 30: 1075-1082.

1970 Use of a dipper nest by Mountain Bluebird. Condor 72: 498.

1971 Temperature relationships and nesting of the Calliope Hummingbird. The Condor, 73(3): 314-321.

1976 Energy Crisis of the Hummingbird. Nat. Hist., 85(5): 24-29.

Carpenter, Charles

1953 Aggregation behavior of tadpoles of Rana p. pretiosa. Herpetologica, 9: 77-78. 
An ecological survey of the herpetofauna of the Grand TetonJackson Hole area of Wyoming. Copeia, 3: 170-174.

1954 A study of amphibian movement in the Jackson Hole Wildlife Park. Copeia, 3: 197-200.

Clark, M. L. and T. W. Clark

1971 Key to 22 selected flowering plants based on leaf epidermal morphology from Jackson Hole, Wyoming. Wyo. Range Mgmt., 288: $52-60$.

Clark, T. W.

1971 Aberrant coloration in Microtus pennsylvanicus from Grand Teton National Park, Wyoming. Northwest. Sci. 45: 226-228.

Seasonal activity, habitat, reproduction and food uses of the western jumping mouse in Grand Teton National Park, Wyoming Northwest. Sci.

Ecology of the western jumping mouse in Grand Teton National Park, Wyoming. Northwest. Sci. 45: 229-238.

Key to twenty-two selected flowering plants of Jackson Hole, Wyoming based on leaf epidermal morphology. Wyo. Range

Manage. 288: 52-60. With M. L. Clark.

1973 Distribution and reproduction of shrews in Grand Teton National Park, Wyoming. Northwest Sci. 47: 128-131.

Local distribution and interspecies interactions in microtines, Grand Teton National Park, Wyoming. Great Basin Nat. 33: 205-217.

1975 Ecological notes on deer mice in Grand Teton National Park, Wyoming. Northwest. Sci. 49: 14-16.

Body measurements of western jumping mice from Northwestern Wyoming. Northwest. Sci. 49: 12-13.

1976 Population organization and regulating mechanisms of pine martens in Grand Teton National Park, Wyoming. Paper presented before First Conference of Scientific Research in National Parks. New Orleans, La., 9-13 Nov., 1976.

1977 Agonistic behavior patterns in the Uinta ground squirrel. Northwest. Sci. 51: 36-42. With C. Russel.

1978 Analysis of pine marten population organization and regulatory mechanisms in Jackson Hole, Wyoming. Nat. Geogr. Soc. Res. Rpts. In Press.

Vocalizations of the American pine marten (Martes americana). $-143-$ 
J. Mammal. 59: 871-874. With I. Belan and P. Lehner.

1980 Short-term logging affects on rodents. Great Basin Nat. 40: 133-189. Wi th T. M. Campbell.

Habitat ecology of pine marten in Grand Teton National Park, Wyoming. To be presented before Northwest Scientific Assoc., March 27-29, University of Idaho, Moscow. With T. Campbell, T. Hauptman, and J. Weaver. Northwest Sci. In Press.

Cody, M. L.

1980 Habitat selection in birds: The roles of vegetation structure, competitors, and productivity. In Press, BIOSCIENCE.

Collins, Thomas C.

1976 Population characteristics and habitat relationships of beavers (Castor canadensis) in northwest Wyoming. PhD Thesis. Univ. of Wyo., Laramie, $177 \mathrm{pp}$.

1979 Stream flow effects on beaver populations in Grand Teton National Park. Proc. First Conf. Sci. Res. Nat. Parks, AIBS-NPS, pp. 349-352.

Craighead, Frank C.

1951 A biological and economic evaluation of coyote predation. N.Y. Aool. Soc. and the Conser. Found. July (booklet)

Craighead, Frank C. and John J. Craighead

1949 Nesting Canada Geese on the Upper Snake River. J. Wildl. Mgmt., 13(1): 51-64.

1950 The ecology of raptor predation. Trans. 15th No. Amer. Wildl. Conf., pp. 209-223.

Craighead, John J.

1952 A biological and economic appraisal of the Jackson Hole elk heard. N.Y. Zool. Soc. and the Conser. Found. (booklet) November.

Cummins, Geroge B. and John W. Baxter

1962 Nomenclature, life histories, and records of North American Uredinales. Madrono, 16(6): 201-203.

Czaplewski, R. L.

1972 Evolution of terminal consumers in a steady state regime. M.S. Thesis, Univ. Wyoming. $54 \mathrm{pp}$.

Czaplewski, R. L. and M. Parker

Use of a BOD oxygen probe for estimating primary product- 
ivity. Limnology and Oceanography. In Press.

Denniston, R. H.

1948 Certain aspects of the behavior of the Wyoming moose J. Colo.-Wyo. Acad. of Sci., 3(6): 55.

1949 The development of a calf moose. J. Colo.-Wyo. Acad. of Sci., $4(1): 58$.

1956 Ecology, behavior and population dynamics of the Wyoming or Rocky Mountain moose, Alces Alces shiras. Zoologica, 41(3): 105-118.

Diem, Kenneth L.

1967 Banding Studies of Water Birds on the Molly Is lands, Yellowstone Lake, Wyoming. Yellowstone Lib. and Mus. Assoc., Yellowstone Nat'l. Park. 41 pp. (With David Del. Condon)

1979 White Pelican reproductive failures in the Molly Islands breeding colony in Yellowstone National Park. Proc. First Conf. Sci. Res. Nat'1. Parks, New Orleans, LA. U.S. Nat'l. Park Ser. Trans. and Proc. Series No. 5. 1:409-496.

Diem, Kenneth L. and Garth S. Kennington

1979 Rhyolite radionuclide uptake by selected plant species and pocket gophers in Yellowstone National Park. Proc. First Conf. Sci. Res. Nat'. Parks, New Orleans, LA. U.S. Nat'1. Park Ser. Trans. and Proc. Series No. 5. 1:301-305.

Dimmick, Ralph W.

1968 Canada Geese of Jackson Hole. Bull. No. 11, Wyo. Game and Fish Comm., Cheyenne. 86 pp.

Edwards, William C.

1964 A preliminary investigation concerning the plant ecology for the willow flats on Jackson Lake, Jackson Hole, Wyoming. Proc. 74 th Ann. Meet. of the Nebr. Acad. of Sci., May 1 \& 2, pp. 6-7.

Emlen, John T.

1952 Social behavior in nesting cliff swallows. Condor, 54: 177199.

1954 Territory, nest building, and pair formation in the cliff swallow. Auk, 71:16-35.

Evans, Howard E.

1962 The geyser-loving digger wasps of Yellowstone. The Explorer, Cleveland, Ohio, 4: 6-11. 
1963 Predatory wasps. Sci. Amer., 208(4): 145-154.

The clustering wasps--and why they cluster. Aud. Mag., 65(4): 236-237. July-August.

Notes on the prey and nesting behavior of some solitary wasps of Jackson Hole, Wyoming. Entomo. News, $74(9)$ : 233-239.

1964 Observations on the ethology of digger wasps of the genus Steniolia (Hymenoptera: Bembicini). Amer. Mid. Nat., 72(2): 257-280. (With J. E. Gillaspy)

1965 Simultaneous care of more than one nest by Ammophila azteca Cameron (Hymenoptera, Sphecidae). Psyche, 72(1): 8-23.

1966 The Comparative Ethology and Evolution of the Sand Wasps. Harvard Univ. Pres, 526 pp.

The accessory burrows of digger wasps. Sci., 152(3721): 465-471.

Nests and prey of two species of Philanthus in Jackson Hole, Wyoming (Hymenoptera, Specidae). Great Basin Nat., 26(1-2): 35-40.

1968 The hunt of the wasps at Jackson Hole. Nat. Hist., 77: 38-39.

1970 Ecological-behavioral studies of the wasps of Jackson Hole, Wyoming. Bull. Mus. Comp. Zool., 140(7): 451-511.

1973 Further studies on the wasps of Jackson Hole, Wyoming (Hymenoptera, Aculeata). Great Basin Nat., 33(3): 147-155.

1978 Alternative mating strategies in the digger wasp Philanthus zebratus Cresson. Proc. of the Nat'1. Acad. of Sci., 75(4): 1901-1903. (With Kevin M. O'Neill)

Findley, James S.

1951 Habitat preferences of four species of Microtus in Jackson Hole, Wyoming. J. Mamma 1., 32(1): 118-120.

A record of moose speed. J. Mammal., 32(1): 116 .

A tame red fox cub. J. Mammal., 32(1): 117.

1954 Reproduction in two species of Myotis in Jackson Hole, Wyoming. J. Mammal., 35(3): 434.

Flack, J. A. Douglas

1970 Bird populations of aspen forests in Western North America. 
University of Wisconsin. (Abstract, Ph.D. Thesis)

1976 Bird Populations of Aspen Forests in Western North America. Ornith. Monogr. No. $19 \mathrm{vii}+97 \mathrm{pp}$., frontis., 56 text figures, appendix.

French, Norman R.

1955 Foraging behavior and predation by Clark Nutcracker. Condor, 57(1): 61-62.

1959 Life history of the Black Rosy Finch. Auk, 76(2): 159-180.

1959 Distribution and migration of the Black Rosy Finch. Condor, $61(1): 18-29$.

French, Norman R. and J. B. French

1965 Rosy Finches of the high Rockies, pp. 422-432. In 0.S.

Pettingill, Jr. (editor) The bird watcher's America.

McGraw Hill Book Co., Inc., New York.

Gartner, Robert

1978 Resources of the North American Prairie. Proc. 1977 Range-

land Management and Fire Symposium. Mont. For. and Conserv.

Exp. Sta., Univ. of Mont. Sch. of For. pp. 6-12.

Gartner, Robert, L. R. Roath and E. M. White

1976 Advantages and disadvantages of prescribed burning. Symposium

Proc. Use of Prescribed Burning in Western Woodland and

Range ecosystems. Utah Agr. Exp. Sta., Utah State Univ. pp. $11-15$.

Gilligan, James $P$.

1954 Wildlife values in western wilderness area management.

J. Wildl. Mgmt., $18(4)$.

Gould, Edwin, Norman C. Negus and Alvin Novick

1964 Evidence for echolocation in shrews. J. Exp. Zool., 156(1): 19-38.

Gourley, R. S. and F. J. Jannett, Jr.

1975 Pine and montane vole age estimates from eye lens weights. J. Wildl. Mgmt., 39: 550-556.

Houston, Douglas B.

1968 The Shiras Moose in Jackson Hole, Wyoming. Grand Teton Nat. Hist. Assoc. Tech. Bull. \#1. 110 pp.

1969 Immobilization of the Shiras Moose. J. Wildl. Mgmt., $33(3): 534-537$. 
Huckabee, John, F. 0. Cartan and G. S. Kennington

1972 Environmental influence on trace elements in hair of 15 species of mammals. Oak Ridge National Laboratory, ORNL-TM-3747. $38 \mathrm{pp}$.

Jannett, F. J., Jr.

1975 The "hip glands" of Microtus pennsylvanicus and $M$. longicaudus (Rhodentia: Muridae), voles "Wi thout" hip glands. Syst. Zool., 24: 171-175.

1978 The density-dependent formation of extended maternal families of the montane vole, Microtus montanus nanus. Behav. Ecol. and Sociobiology, 3: $\overline{245-263 .}$

1978 Dosage response of the vesicular, preputial, anal, and hip glands of the male vole, Microtus montanus (Rhodentia: Muridae), to testosterone propionate. J. Mammal., 59: 772-779.

Social dynamics of the montane vole, Microtus montanus as a paradigm. Biologist, In Press.

Jannett, F. J., Jr. and R. A. Stehn

Male-induced abortion in various microtine rodents. J. Mammal., In Press.

Jannett, F. J., Jr. and J. Z. Jannett

1974 Drum-marking by Arvicola richardsoni and its taxonomic significance. Amer. Mid. Nat., 92: 230-234.

Convergent evolution in the behavior of a shrew and a rodent. Mammalia, In Press.

Jannett, F. J., Jr. and J. Z. Jannett and M. E. Richmond

1979 Notes on reproduction in captive Arvicola richardsoni. J. Mammal., 60: 837-838.

John, Kenneth R.

1957 Comparative rates of survival of normal and deformed chub, Gila atraria Girard, in Two Ocean Lake, Teton County Wyoming. Proc. Pa. Acad. of Sci., 31: 77-82.

1959 Ecology of the chub, Gila atraria with special emphasis on vertebral curvatures in Two Ocean Lake, Teton National Park, Wyoming. Ecol., 40(4): 564-571.

Jones, Webster B.

1965 Response of major plant species to elk and cattle grazing in Northwestern Wyoming. J. Range Mgmt. 18(4): 218-220.

Kennington, Garth S.

1957 Influence of altitude and temperature upon rate of oxygen 
consumption of Tribolium confusum Duval and Camponotus pennsylvanicus modoc Wheeler. Physiol. Zool., 39(4): 305-314.

1961 The influence of temperature and atmospheric pressure on the rate of oxygen uptake in Tribolium confusum. Ecol. $42(1): 212-215$.

Kingston, Newton; K. L. Diem; \& D. Mitchum

1980 Diphyplloborthrium Cordecips: A tapeworm problem in Yellowstone Lake fishes. New investigation into life cycle. Proceedings of the 2 nd meeting of Scientific Research in National Parks. Volume 2 pp. 141-162.

Knapp, Alan K. and William K. Smith

1981 Water relations and succession in subalpine conifers in Southeastern Wyoming. The University of Chicago.

Kroger, Richard L.

1970 An annotated list of stream invertebrates collected from Grand Teton National Park, Wyoming. Univ. of Wyo. Publ., 36(1): 1-14. July 15 .

Laycock, William

1953 Ecological notes on the pocket gopher in Wyoming. J. ColoWyo. Acad. of Sci., 4(5): 41.

1957 Seasonal periods of surface inactivity of the pocket gopher. J. Mammal., 38(1): 132-133.

1958 The initial pattern of revegetation of pocket gopher mounds. Ecol., 39(2): 346-351.

Levi, Herbert W. and Lorna R. Levi

1951 Report on a collection of spiders and harvestmen from Wyoming and neighboring states. Zoologica, 36 (LV): 219-237.

Lichtwardt, Robert W.

1967 Zygospores and spore appendages of Harpella (Trichomycetes) from larvae of Simuliidae. Mycologia 59(3): 482-491.

1972 Undescribed genera and species of Harpellales (Trichomycetes) from the guts of aquatic insects. Mycologia 64(1): 167-197.

Loudenslager, E. J. and G. H. Thorgaard

1979 Karyotypic and evolutionary relationships of the Yellowstone (Salmo clarki bouvieri) and the westslope (s. c. lewisi) cutthroat trout. J. Fish. Res. Bd. Canada $36: 360-365$.

Loudenslager, E. J. and R. M. Kitchin

1979 Genetic similarity between two forms of cutthroat trout, 
Salmo clarki, from Wyoming. Copeia 1979: 673-678.

Loudenslager, E. J. and G. A. E. Gall

1980 Geographic patterns of protein variation and subspeciation in cutthroat trout, Salmo clarki. Syst. Zool. 29: 27-42.

Lowrie, Donald C.

1955 A list of the spiders of the Grand Teton Park area, with descriptions of some new North American spiders. Amer. Mus. Novit., No. 1736: 1-29 (With Willis J. Gertsch)

1967 Some life history data on several species of common spiders from the Jackson Hole area of Wyoming. Bull. So. Calif. Acad. of Sci., $66(2): 142-146$.

1968 The spiders of the herbaceous stratum of Jackson Hole region of Wyoming. Northwest Sci., 42(3): 89-100.

Lynch, J. C. and E. R. Vyse

1979 Genetic variability and divergence in grayling, Thymallus arcticus. Genetics 92: 263-278, 1979.

MacLeod, Ellis G.

1971 Studies on the biology of the Chrysopidae. II. The feeding behavior of the adult of Chrysopa carnea (Neuroptera). Psyche, 78(1-2): 107-121. (With Joseph K. Sheldon).

Marshall, Kent G., Dennis H. Knight and William J. Barmore

1979 An indexed and annotated bibliography on the ecology of Grand Teton National Park. U.W.-N.P.S. Res. Center, Moran, WY.

McFeters, G. A.; S. A. Stuart and S. B. Olson

1978 Growth of heterotrophic bacteria and extracellular products in oligotrophic waters. Appl. Environ. Microbiol. 35: 383-391.

1978 Interactions of algae and heterotrophic bacteria in an oligotrophic stream. Proc. LIfe Sci. Microbial Ecol. M. W. Loutit \& J. A. R. Miles (eds), pp. 57-61. Apringer Verlag, New York.

McKnight, Kent $\mathrm{H}$.

1969 A note on Discina. Mycologia, 61(3): 614-630. May-June.

1971 On two species of false morels (Gyromitra) in Utah. Great Basin Nat., 31(2): 35-47.

Miller, Dwight D.

1955 A study of sex combs in Drosophila affinis and Drosophila athabasca. Trans. of the Amer. Microscop. Sox., 74(2): 191-197. 
Nakamura, Mitsuru

1950 A survey of Pasteurella tularensis infection in the animals of the Jackson Hole area. Zoologica, 35(11): 129-131.

Negus, Norman C.

1950 Breeding of three-year-old females in the Jackson Hole Wildlife Park buffalo herd. J. Mammal., 31(4): 463.

Fluctuation in the population of Neotoma cineria (woodrat) in Jackson Hole, Wyoming. J. Mammal., 31(2): 196-197.

Habitat adaptability of Phenocomys in Wyoming. J. Mammal., $31(3): 351$.

1959 Mammals of Jackson Hole, Wyoming. J. Mamma l., 40(3): 371-381. (With James S. Findley)

1971 Pineal weight response to a dietary variable. Experientia, 27(2): 215-216. (With Patricia J. Berger)

Activity rhythms in Microtus montanus: the role of the pineal gland. Submitted to J. of Exper. Zool. (With Patricia J. Berger)

The dynamics of Microtus montanus populations in Jackson Hole, Wyoming from 1960-1970.

Noble, Glenn A.

1953 An intestinal amoeba from the prong-horned antelope.

Trans. of the Amer. Microscop. Soc., 72(3): 249-252.

1958 Coprozoic protozoa from Wyoming mammals. J. Protozool., $5(1): 69-74$.

1961 Stress and Parasitism. I. A preliminary investigation of the effects of stress on ground squirrels and their parasites. Exper. Parasit., 11(1): 63-67.

1962 Stress and Parsitism. II. Effect of crowding and fighting among ground squirrels on their Coccidia and Trichomonads. Exper. Parasit., 12(5): 368-371.

1966 Stress and Parasitism. III. Reduced night temperature and the effect on pinworms of ground squirrels. Exper. Parasit., 18(1): 61-62.

Stress and Parasitism. IV. Cold stress and Entamoeba. Exper. Parasit., 19(3): 264-268.

Patterson, Robert L.

1952 Sage Grouse in Wyoming. Sage Books, Denver, Colorado. 
Pinter, Aelita J.

1965 Effects of nutrition and photoperiod on reproductive physiology of Microtus montanus. Amer. J. Physiol., 280: 633-638. (With N. C. Negus)

Litter sizes of Microtus montanus in the laboratory. J. Mamma 1., 46: 434-437. (With N. C. Negus)

1966 Responses of Microtus montanus to plants and plant extracts in the diet. J.Mammal., 47: 596-601. (With N. C. Negus)

1968 Effects of diet and light on growth, maturation and adrenal size of Microtus montanus. Amer. J. Physiol., 215: $828-832$.

1970 Hereditary hairlessness in the montane vole, Microtus montanus. J. Heredity, 61: 112-114. (With A. K. McLean)

1971 Coat color mutations in two species of the vole (Microtus montanus and Microtus ochrogaster) in the laboratory. J. Mammal., 52: 196-199. (With N. C. Negus)

1972 A new naturally occurring dominant mutation in Microtus montanus from Jackson Hole, Wyoming. Ann. Meet. Amer. Soc. of Mammal., Tampa, Florida, 18-22 June, 1972 (Abstract).

1973 Pink-eyed dilution in a natural population of the Uinta ground squirrel. J. Heredity, 64(2): 106.

1974 Some aspects of population dynamics in the mountain vole, Microtus montanus (Rodentia). First Int'l. Theriol. Cong., Moscow, USSR, 6-12 June, 1974 (Abstract).

1976 The weight of the spleen, adrenals and gonads during a chronic Trypanosoma brucie gambiense infection in laboratoryreared Microtus montanus. Amer. Mid. Nat., 96: 379-390. (With J.R. Seed, P. U.Ashman, S. Ackerman and L. King)

Reproductive responses as a factor in the population dynamics of small mammals. In: Symp. on the Ecol. Aspects of Reprod. of Mammals. 56 th Ann. Meet. Amer. Soc. of Mamma 1., Lubbock, Texas, 20-24 June (Abstract).

1978 Comparison of organ weights of wild and laboratory-reared Microtus montanus infected with Trypanosoma brucie gambiense.

(With J. R. Seed, P. U. Ashman, S. Ackerman and L. King)

Population dynamics of Microtus montanus, over nine years. Second Int'l. Theriol. Cong., Brn., Czechoslovakia, 20-27 June (Abstract). 
1979 Environmental variables and multiannual cycles in population density of the montane vole, Microtus montanus, in Grand Teton National Park - a pre] iminary report. Proc. First Conf. Sci. Res. Nat'1. Parks, New Orleans, LA, 9-12 November, 1: $279-285$.

Erroneous report of extreme dilution $\left(c^{e}\right)$ in Microtus pennsylvanicus. J. Heredity, 70: 213-214.

Dominant spotting from a natural population of the vole, Microtus montanus. J. Heredity, 70: 441-443.

Pontius, R. A.

1972 Studies on the uptake of nitrate and ammonium by phytoplankton. M.S. Thesis, Univ. Wyo. 124 pp.

Pontius, R. W. and M. Parker

1972 Food habits of the Mountain Whitefish, Prosopium williamsoni (Girard). In revision for Tran. Amer. Fish. Soc.

Rausch, Robert

1949 Paradilepsis simonin. sp., a cestode parasitic on the osprey. Zoologica, 34 (1).

A contribution to the study of North American cestodes of the genus Paruterina Fahrmann, 1906. Zoologica, 34(1). (With Everett Schiller).

Reed, John F.

1948 Botanical investigations in the Jackson Hole Wildlife Park. J. Colo-Wyo Acad. of Sci., 3(6): 40.

1950 The meadows of the Jackson Hole Wildlife Park. J. Colo-Wyo Acad. of Sci., 4(2): 53.

1952 The vegetation of the Jackson Hole Wildlife Park, Wyoming. Amer. Mid. Nat., 48(3): 700-729.

Romme, William H.

1980 Fire frequency in subalpine forests of Yellowstone National Park. Paper presented at the Fire History Workshop, October 20-24, 1980, Tucson, Arizona sponsored by Rocky Mountain Forest and Range Experiment Station and Laboratory of Tree-Ring Research. (A printed proceedings of this conference, containing this paper, will be published some time early in 1981, and will appear probably as a General Technical Report of the Rocky Mt. Station, U.S. Forest Service).

Fire frequency in subalpine forests of Yellowstone National Park. Proc. Fire History Workshop. Rocky Mtn. For. and 
Range Exp. Sta., Ft. Collins, C0, Gen. Tech. Rept. RM-810 pp. $27-30$.

Fire history terminology: report of the AdHoc Committee. Proc. Fire History Workshop. Rocky Mtn. For. and Range Exp. Sta., Ft. Collins, CO. Gen. Tech. Rept. RM-81. pp. $135-137$.

Roome, William H. and Dennis H. Knight

1979 Fire and landscape diversity in Yellowstone National Park. Bull. Ecol. Soc. Amer., 60(2): 102. (Abstract)

1979 Fire and landscape diversity in Yellowstone National Park. Paper presented at the 2nd Conference on Scientific Research in the National Parks, 26-30 November 1979, San Francisco, California, sponsored by U.S. National Park Service.

1981 Fire frequency and subalpine forest succession along a topographic gradient in Wyoming. Ecol. (In Press)

In Press. Landscape diversity: the concept and and application to lake productivity and wildlife in Yellowstone National Park. Bio-Science.

Roofe, Paul G.

1960 The rate of flow of blood through capillaries in the olfactory lobe of the brain of Amblystoma tigrinum.

Anat. Rec., 138(2): 159-162.

1961 Blood constituents of Ablystoma tigrinum. Anat. Rec., 140(4): 337-340.

Weights and linear measurements of the body and of some organs of the tiger salamander. Anat. Rec., 141(1): 35-44. (With Homer B. Latimer and Lily S. Feng).

1964 Weighta and linear measurements of the body and organs of the tiger salamander, before and after metamorphosis, compared with the adult. Anat. Rec., 148(2): 139-147.

Salt, George W.

1957 An analysis of avifaunas in the Teton Mountains and Jackson Hole, Wyoming. Condor, 59(6): 373-393.

Schaller, G. B.

1964 Breeding behavior of the White Pelican at Yellowstone Lake, Wyoming. Condor, 66(1): 3-23.

Scherba, Gerald

1961 Nest structure and reproduction in the mound-building ant Formica opaciventris Emery in Wyoming. J. of the N.Y. Ent. 
Soc., 69: 71-87.

1963 Population characteristics among colonies of the ant Formica opaciventris (Hymenoptera:Formicedae). J. of the N.Y. Ent. Soc., 71: 219-232.

1964 Analysis of inter-nest movement by workers of the ant Formica opaciventris (Hymenoptera:Formicedae). An. Behav., $12(4): 508-512$.

Species replacement as a factor affection distribution of Formica opaciventris Emery (Hymenopter: Formicidae). J. of the N.Y. Ent. Soc., 72: 231-237.

An analysis of inter-nest movement by workers of the ant, Formica opaciventris. Amer. Zool., 4(3): 162.

1965 Observations on Microtus nesting in ant mounds. Psyche, $72(2): 127-132$.

Schripsema, J. R.

1977 Ecological changes on pine-grassland burned in spring, late spring and winter. M.S. Thesis, S. Dak. State Univ., Brookings. $99 \mathrm{pp}$.

Simon, James R.

The American Elk or Wapiti. Wildlife Series No. 1, Jackson Hole Wildlife Park.

The Wyoming or Yellowstone Moose. Wildlife Series No. 2, Jackson Hole Wildlife Park.

Smith, Dixie R.

1959 Changes in interspecific associations as related to grazing pressures. J. Range Mgmt., 12(6): 309-311.

1960 Description and response to elk use of two mesic grassland and shrub communities in the Jackson Hole region of Wyoming. Northwest Sci., 34(1): 25-36.

1961 Competition between cattle and game on elk winter range. Wyo. Ag. Exp. Sta. Bull. 377, 16 pp.

Solheim, W. G.

1960 Mycoflora Saximontanensis Exsiccata. Centum XI and XII. Univ. Wyo. Publ., $24(3 \& 4): 22-23 ; 34-55$.

1970 Mycoflora Saximontanensis Exsiccata. Centum XIV. Univ. Wyo. Publ., $36(4): 51-67$. July 15.

Solheim, W. G. and George B. Cummins 
1970 Mycoflora Saximontaneses Exsiccata. Centum XIII. Univ. Wyo. Publ., 36(3) 37-50 July 15.

Mycoflora Saximontanensis Exsiccata. Centum XV. Univ. Wyo. Publ., 36(5): 69-80. July 15.

Spencer, Warren $P$.

1950 The Drosophila of Jackson Hole, Wyoming--a Taxonomic and ecological survey. Amer. Mid. Nat., 43(1): 79-87.

Stuart, Sidney A., Gordon A. McFeters, John E. Schillinger and David

G. Stuart

1976 Aquatic indicator bacteria in the high alpine zone. Appl. and Envir. Microbiol., 31(2): 163-167.

Sutton, John F. and Craig C. Black

1975 Paleontology of the earliest oligocene deposits in Jackson Hole, Wyoming. Part 1. Rodents exclusive of the Family eomyidae. Annals of Carnegie Mus., 45(16): 299-315.

Thornton, Charles Stead

1956 Epidermal modifications in regenerating and in nonregenerating limbs of anuran larvae. J. Exp. Zool., 131(2): 373-394.

The relation of epidermal inndrvation to the regeneration of $1 \mathrm{imb}$ deplants in Amblystoma larvae. J. Exp. Zool., 133(2): 281-300.

1957 The effect of apical cap removal on limb regeneration in Ablystoma larvae. J. Exp. Zool., 134(2): 357-382.

1958 The inhibition of limb regeneration in urodele larvae by localized irradiation with ultraviolet light. J. Exp. Zool., 137(1): 153-180.

1960 Influence of an eccentric epidermal cap on limb regeneration in Ablystoma larvae. Dev. Bio., 2(6): 551-569.

Regeneration of asensory limbs of Amblystoma larvae. Copeia, No. 4, pp. 371-373, Dec. 30 .

Thurmond, William

1967 Hypothalamic chromatophore-stimulating activity in the amphibians Hyla regilla and Ambystoma tigrinum. Gen. and Comp. End., 8(2): 245-251.

Onset of chromatophore-stimulating activity by the hypothalamus and adenohypophys is in Hyla regila and Ambystoma tigrinum. Gen. and Comp. Endo., 8(2): 252-257. 
Intermedin-like activity by the pars distalis of the salamander Ambystoma tigrinum. Amer. Zool., 7(2): 7, May.

1968 Onset of melanophore-stimulating activity of the pars distalis and pars intermedia of the tiger salamander Ambystoma triginum melanostictum. Amer. Zool., 8(4): 113, November.

Tiner, Jack D.

1951 Observations on larval carnivore ascarids in rodents. J. Parasit., 37(Sup.): 21-22.

1952 Speciation in the genus Ascaris: Additonal experimental and morphological criteria. J. Parasit., 38(Sup.) : 57.

1953 The migration, distribution in the brain, and growth of ascarid larvae in rodents. J. Infect. Dis., 92: 105-113.

Fatalities in rodents caused by larval Ascaris in the central nervous system. J. Mammal., 34: 153-167.

Wi ley, Robert W.

1969 Snake River Cutthroat Trout Study, Part II: An ecological evaluation of the Snake River cutthroat trout fishery with emphasis on harvest. Coop. Res. Proj. \#4, Wyo. Game \& Fish Comm., June 1969.

Williams, 01 wen

1959 Food habits of the derr mouse. J. Of Mammal., 40(3): 413-419.

Worcester, L. L.

1970 Effects of prescribed burning at different fuel moisture levels on vegetation and soils of grasslands in Wind Cave National Park. M.S. Thesis, S. Dak. State Univ. Brookings. $101 \mathrm{pp}$.

Zeveloff, S. I.

1980 The population status of Canada geese in Jackson Hole. J. Colo-Wyo. Acad. Sci., 12(1): 40. 